\title{
'And thou shalt teach these words diligently ...': Remarks on the purpose of the Heidelberg Catechism regarding its teaching nature
}

\author{
Author: \\ Victor E. d'Assonville ${ }^{1,2}$ \\ Affiliations: \\ ${ }^{1}$ Faculty of Theology, \\ University of the Free State, \\ South Africa \\ ${ }^{2}$ Reformatorisch- \\ Theologisches \\ Predigerseminar, Germany \\ Correspondence to: \\ Victor d'Assonville \\ Email: \\ vicdas@xsinet.co.za \\ Postal address: \\ PO Box 85, Faerie Glen 0043 \\ South Africa \\ Dates: \\ Received: 14 Dec. 2012 \\ Accepted: 11 July 2013 \\ Published: 16 Oct. 2013 \\ How to cite this article: \\ D’Assonville, V.E., 2013, \\ "'And thou shalt teach \\ these words diligently ..." \\ Remarks on the purpose of \\ the Heidelberg Catechism \\ regarding its teaching \\ nature', In die Skriflig/In \\ Luce Verbi 47(2), Art. \#679, \\ 7 pages. http://dx.doi. \\ org/10.4102/ids.v47i2.679 \\ Note: \\ This contribution is based \\ on a paper delivered on 11 \\ May 2012 at the second \\ Refo500 Conference in Oslo, \\ Norway. My appreciation \\ goes to Deborah Stein for her \\ thorough and diligent text \\ editing.

\section{Copyright:} \\ (C) 2013. The Authors. \\ Licensee: AOSIS \\ OpenJournals. This work \\ is licensed under the \\ Creative Commons \\ Attribution License. \\ Read online:

Scan this QR
code with your
smart phone or
mobile device

As is well-known, the Heidelberg Catechism (HC) has not only become one of the most important confessions of faith since the 16th century, it has also been a significant aid to catechesis, even to this day. In this contribution, the catechetical purpose of the HC is examined with regard to its origins. Three texts that accompanied the first editions of the Heidelberg Catechism in 1563 are scrutinised: two prefaces by Frederick III, and the Palatine Church Order. The youth as well as the rest of the congregation, should be guided in the fear of the Lord so that they may attain sufficient knowledge of and a living faith in the Lord of Scripture. The HC does not merely have theoretical purposes. Its contents and structure were carefully composed to teach the most significant parts of Christian faith in a short and simple way on a regular and frequent basis. This teaching is not only the responsibility of the church or minister, but also of the parents and the teachers. In this comprehensive approach to instruction in the Christian faith, there is no contradiction between Scripture as the Word of God and the HC. Hence, teaching and preaching the HC does justice to the command that the gospel should be proclaimed, preached, taught, learned and understood.

'En hierdie woorde ... moet $[j y]$ jou kinders inskerp': Opmerkings oor die doel van die Heidelbergse Kategismus met verwysing na sy onderrigkarakter. Dit is algemeen bekend dat die Heidelbergse Kategismus nie net een van die belangrikste geloofbelydenisse sedert die sestiende eeu is nie, maar ook ' $n$ buitengewone kategetiese hulpmiddel was en steeds is. In hierdie bydrae word die kategetiese doel van die Heidelbergse Kategismus onder die loep geneem met verwysing na die ontstaansgeskiedenis daarvan. Drie tekste uit die eerste jaar van die kategismus se 1563-uitgawe, naamlik twee verskillende voorwoorde deur Frederik III en die Kerkorde van die Palts word daarvoor ondersoek. Die jeug sowel as die res van die gemeente moet in die vrees van God tot voldoende kennis en 'n lewende geloof in die Here van die Skrif gelei word. Die Heidelbergse Kategismus het nie net teoretiese betekenis nie. Die inhoud en struktuur daarvan is noukeurig saamgestel om die jeug, sowel as die hele gemeente oor die belangrikste stukke van die Christelike geloof op 'n kort en eenvoudige manier asook op 'n gereelde basis, te onderrig. Die onderrig is nie die verantwoordelikheid van die kerk of die predikant alleen nie, maar ook dié van ouers en onderwysers. In hierdie omvattende benadering is daar geen teenstrydigheid tussen die Skrif as die Woord van God en die Heidelbergse Kategismus nie. Gevolglik laat die onderwys en die prediking van die Heidelbergse Kategismus reg geskied aan die opgawe dat die evangelie verkondig, gepreek, onderrig sowel as geleer en verstaan moet word.

\section{A confession, a book of comfort ... And a catechism}

During the 450th commemoration of the HC in 2013, and with the prospect of many a jubilee, a discussion of the importance and influence of this 'little book' over the past four and a half centuries would hardly be ground-breaking. People living in Germany would perhaps be astonished to know that there are regions in the world where the name Heidelberg does not only refer to a city, but also to a catechism. This should come as no surprise as the Heidelberg Catechism, ${ }^{1}$ featuring in the same premier league as Luther's Small Catechism and the Westminster Catechism, is regarded by many a scholar as one of the most important confessions of faith in this form since the Reformation. ${ }^{2}$ Some even regard it as the 'most well-known confession of the church' (Van 't

1.For references to the original textus receptus of 1563 , the latest standard text critical edition by Wilhelm $\mathrm{H}$. Neuser in the series, Reformierte Bekenntnisse (cf. Neuser 2009), was used.

2.In the English-speaking Reformed and/or Presbyterian world, the Westminster Shorter Catechism has the same status and popularity as Luther's Small Catechism in the Lutheran world and the Heidelberg Catechism in the continental, North American, South African and Asian, especially the Korean, Reformed and/or Presbyterian world. 
Spijker 2005), 3' 'a document that has proven itself to be an enduring and inspiring monument to the Reformed faith' (Gunnoe 2005:15). The number of translations, republications and reprints of the HC in the time directly after 1563 bears witness to the fact that, even then, it was 'one of the most significant texts of the reformed church' (Sehling 1969:43), whilst in modern times it has maintained its status as one of the most translated confessions of faith across the world.

Although much has been said about the origins, structure and the contents of this little compendium of reformed faith, with its 129 easily surveyable questions, and even though one can almost anticipate the research, lectures and publications on the HC that will emerge during 2013, many themes will perhaps not be investigated in much depth at all. One of them would seem to be a theme that is at first glance conceivably obvious, yet when considered more thoroughly, is actually one of the most complicated subjects regarding the $\mathrm{HC}$ - namely the whole matter of catechetics itself, which concerns the teaching of the confession.

That the HC, not least since its conception, was meant as an aid to catechesis is not only evident from its outline as a catechism, but also from the title it has borne right from the first edition: 'Catechism or Christian instruction as it is practised in churches and schools of the Electoral Palatinate' (Sehling 1969:41). ${ }^{4}$

The interest in the $\mathrm{HC}$, however, is not only concerned with the confession as a historical phenomenon. An investigation of its catechetical aspect is also worthwhile due to the fact that the HC, after four and a half centuries since its initial publication, continues to be one of the most widely used catechisms, that is textbooks for teaching children and adults in the world (cf. Faulenbach 2002:3, 6; Gruch 1996:8). Various theological reasons could be given to explain why a 'pedagogical textbook' dating back to the 16th century is still used so extensively as a catechism on various continents and in a variety of translations. However, an examination of these considerations would exceed the scope of this article. ${ }^{5}$ This enquiry is therefore limited to an analysis of remarks made in three key texts that accompanied the HC in its first year of publication. These are two prefaces by Frederick III, prince-elector of the Palatinate as well as the Church Order all three from 1563 :

1. The preface of Frederick III to the first edition of the HC, 19 January 1563 (Frederick III 2009:174-175).

2. The preface of Frederick III to the first edition of the Palatine Church Order in which the third edition (sometimes spoken of as the fourth, since it was a republication of the third edition) of the $\mathrm{HC}$ was published - the text of the HC, which ultimately became the textus receptus (cf. Neuser 2009:172), ${ }^{6} 15$ November 1563 (Frederick III 1969:333-335).

3.Refer to the back cover of Van 't Spijker (2005): "Het bekendste belijdenisgeschrift van de kerk - dat was en is de Heidelbergsche Catechismus.

4.'Catechismus oder christlicher underricht, wie der in kirchen und schulen de churfürstlichen Pfaltz getrieben wirdt' (Sehling 1969:41).

5.For the relationship between the pedagogical and confessional aspects of the Heidelberg Catechism, cf. inter alia Hollweg (1968:9-37).

6.'Allgemein wird die Pfälzische Kirchenordnung vom 15. November 1563 als "textus receptus" angesehen. Doch wurden unter dem 5. März 1563 auf kurfürstlichen Befehl Exemplare an die Superintendenten versandt. Es kann sich dabei nur um den fertigen Text der dritten Ausgabe gehandelt haben. Wir nennen ihn daher den "textus receptus" und drucken ihn ab. Ihn sandte Olevian am 3. April an Bullinger, die ebenfalls
fertig gedruckte lateinische Ausgabe an Calvin und Beza' (Neuser 2009:172).
3. The Palatine Church Order of 1563 (in Sehling 1969:335408).

\section{Preface to the first edition of the Heidelberg Catechism (1563)}

In his preface to the first edition of the HC in January 1563, Frederick III discusses the reasons why there was an urgent need for a catechism of this nature. First of all, he emphasises the fact that a good government not only has the task of taking care of various aspects of its subjects' lives - leading them in decent, honest and virtuous conduct - but it also has to guide and instruct them into the righteous insight and fear (reverence) of God Almighty and his Word of salvation as the only foundation of all virtues and obedience (Frederick III 2009:174). ${ }^{7}$ He expresses his concern that, due to the lack of a good catechism and a thorough education, the youth of his principality are growing up without the fear of God or knowledge of his Word (Frederick III ibid:174). ${ }^{8}$

Frederick III stresses the fact that the youth should be 'instructed'. He uses the German verb 'underweisen' [instruct or teach] and the German noun 'underweisung' [instruction or teaching] no less than five times in this short preface (Frederick III 2009:174, 35/37; 175, 12/14/24). He does this in combination with other terms like educate ('aufferzogen'; Frederick III ibid:175, 24), trained ('geübt'; Frederick III ibid:175,3) or teaching/instruction ('Un[d]terricht'), which, as a noun, is also used as a synonym for catechism in the title; Frederick III ibid:174, 1) as well as twice near the end of the preface ('underricht od[er] Catechismum'; Frederick III ibid:175,9; 'Catechismum od[er] Underricht'; Frederick III ibid:175, 18). Frederick III's use of these concepts stresses the dynamic, lively and active way in which he viewed the whole topic of catechetics and the indispensable role of a catechism, in this case the $\mathrm{HC}$, in it.

When considering this, it is noteworthy that the address of Frederick III - not only to the ministers, preachers and 'church servants' (the 'Pfarrherrn' or 'Predigern' as well as 'Kirchen[-dienern]'), but also to the school teachers (Schuldienern) - relates to his aim for the catechism, namely that the $\mathrm{HC}$, as an aid for the teaching of the youth, has a comparably important role in the schools, as in churches (congregations). Later on (Frederick III 2009:175, 11-12) he speaks again about churches and schools, preachers and schoolteachers or schoolmasters (Schulmeister). In his

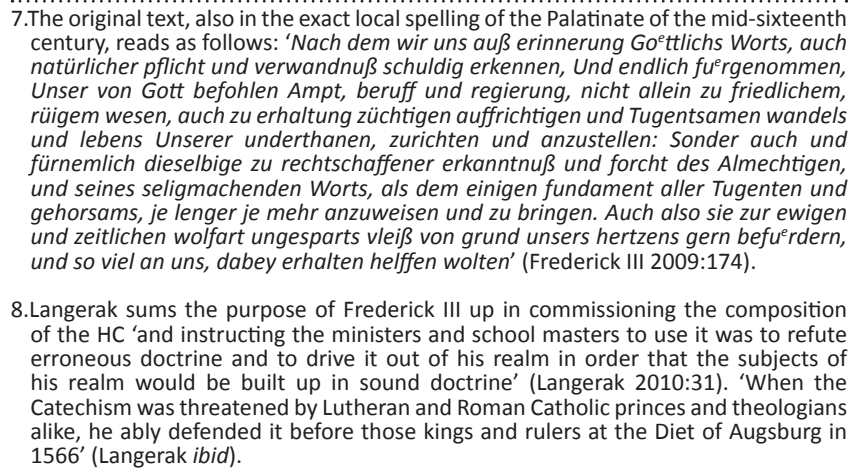

The mid-sixteenth century, reads as follows: 'Nach dem wir uns auß erinnerung Goettlichs Worts, auch natürlicher pflicht und verwandnuß schuldig erkennen, Und endlich fuergenommen, Unser von Gott befohlen Ampt, beruff und regierung, nicht allein zu friedlichem, rüigem wesen, auch zu erhaltung züchtigen auffrichtigen und Tugentsamen wandels und lebens Unserer underthanen, zurichten und anzustellen: Sonder auch und fürnemlich dieselbige zu rechtschaffener erkanntnuß und forcht des Almechtigen, und seines seligmachenden Worts, als dem einigen fundament aller Tugenten und gehorsams, je lenger je mehr anzuweisen und zu bringen. Auch also sie zur ewigen und zeitlichen wolfart ungesparts vleiß von grund unsers hertzens gern befuerdern, of the $\mathrm{HC}$ 'and instructing the ministers and school masters to use it was to refute erroneous doctrine and to drive it out of his realm in order that the subjects of his realm would be built up in sound doctrine' (Langerak 2010:31). 'When the 'Catechism was threatened by Lutheran and Roman Catholic princes and theologian 1566' (Langerak ibid). 
description of the deplorable state of the youth in the Palatine electorate or principality ('Churfürstentum'), he speaks about 'schools and churches of our electorate' where the youth have an insufficient knowledge of Christian doctrine (and in some places no knowledge at all) due to the lack of a solid, uniformly applied catechism. However, not only the churches and schools are mentioned or addressed. Besides Christian and worldly offices ('Christliche und weltliche ämpter') as well as state authority ('Regiment'), Frederick III also discusses families ('haußhaltungen'; Frederick III 2009:174, 40). At the end of his address, he once again raises the matter of the youth in 'schools and churches' and even mentions the 'pulpit' ('auff der Cantzel'), clearly signifying preaching (Frederick III ibid:175, 21).

The fact that Frederick III addresses schools and churches, teachers and ministers in the same breath is indicative of his holistic outlook on education and teaching - a view generally shared by all the Reformed. Religious teaching is not restricted to the 'church'. It is not only the minister's responsibility to teach a child Scripture. When this view (i.e. the inherent relevance and application of Christian instruction to every aspect of human endeavour) is combined with the reformed emphasis on the proclamation and teaching of the gospel, it may have more implications for our comprehension of the $\mathrm{HC}$ than is usually considered when studying it. The clause in life and in death $h^{9}$ in the introductory question of the $\mathrm{HC}(\mathrm{Q} / \mathrm{A}$ 1 ) is therefore meant to be comprehensive and all-inclusive.

The point of departure for Frederick III, near the beginning of his preface, is 'the knowledge and fear of the Almighty' and his saving Word ('seligmachendes Wort'). This principle, 'the knowledge and fear of the Almighty', brings to mind Proverbs 1:7a: 'The fear of the LORD is the beginning of knowledge', and stands at the centre of catechetics. Later on in the preface, when giving the reasons for the need for the $\mathrm{HC}$, he points to a condition that is the opposite of Proverbs 1:7 - youth that 'have grown up without fear of God and knowledge of his Word', because 'they have had no co-ordinated teaching' ('keine eintrechtige underweisung'; Frederick III 2009:174, 37).

The Erkenntnis [knowledge] mentioned here is a constant theme running through the preface - as it is throughout the $\mathrm{HC}$ itself. In this regard, one should take into account that in German there is an important distinction between mere Kenntnis and Erkenntnis - the latter has a kind of comparative or even superlative effect, that is it is a more intensive form of Kenntnis. In English, both words are usually translated as 'knowledge', although the German concept of Erkenntnis implies knowledge as well as acknowledgment. However, in the HC and in Frederick III's preface, 'knowledge' should be understood against the backdrop of faith, as it is formulated in Q/A 21, where 'knowledge' is the translation for Erkenntnis - or erkanntnuß in the old German of the Palatinate (Heidelberger Katechismus 2009):

What is true faith? True faith is not only a sure knowledge whereby I hold for truth all that God has revealed to us in His

9.In my view, taking into account the original German formulation, this clause could be better be translated as: 'whilst I am living and when I am dying'.
Word, but also a hearty trust, which the Holy Spirit works in me by the Gospel, that not only to others, but to me also, forgiveness of sins, everlasting righteousness, and salvation are freely given by God, merely of grace, only for the sake of Christ's merits. (p. $180)^{10}$

The point that Frederick III makes is explicit. In his first paragraph, he begins with the Word of God, and in his last paragraph he once again emphasises that teaching and education should be 'in the Word of God'. ${ }^{11}$ For him, there is no contradiction between Scripture as the Word of God and the HC. The Word of God itself is taught when the HC is taught. This reminds one of Bullinger's expression 'praedicatio verbi Dei est verbum Dei' as a marginal note to his Confessio helvetica posterior (1562/1566), dating from the same period as this preface by Frederick III. ${ }^{12}$

\section{Preface to the first edition of the Palatine Church Order (1563)}

Almost ten months after Frederick III wrote his preface to the first edition of the HC on 18 January 1563, he again addresses the deans (superintendenten), ministers and preachers as well as the 'church and school servants [= teachers]' in a similar way. This time he does it in his preface to the Palatine Church Order on 15 November 1563 (Frederick III 1969:333). He commences by recapitulating the key reasons for publishing the HC. Referring to the many blunders and inconsistencies in the teaching and education of the youth as well as the consequent misunderstandings and lack of order, he expresses the desire that the Catechism would be a remedy for these deficiencies. The future teaching would be reliable and consistent.${ }^{13}$ It is apparent from this that the aim of the 'father' of the HC was to present a standard textbook, a kind of 'handbook', with regard to the content as well as the method according to which the youth should be educated. He speaks about this catechism as a summary of the teaching ('summarische[r] underricht') of our Christian religion from the 10.'[21.] Frag. Was ist warer glaub? Antwort

Es ist nicht allein ein gewisse erkanntnuß, darduch ich alles fue $r$ war halte, was uns Gott in seinem wort hat offenbaret [Heb. 11(, 1-3) lacob. 2(, 19)]: sonder auch ein hertzliches vertrawen [Rom. 5(, 1) et 10(, 10)], welches der heilige Geist [2. Cor. hertzliches vertrawen [Rom. 5(, 1) et 10(, 10)], welches der heilige Geist [2. Cor. $4(, 13)$, Ephes. $2(, 8)]$ durchs Evangelium in mir würcket $[$ Rom. 1(, 16)], daß nicht
allein andern, sonder auch mir vergebung der Sünden, ewige gerechtigkeit und allein andern, sonder auch mir vergebung der Sünden, ewige gerechtigkeit und
seligkeit von Gott geschenckt sey [Heb. 2[,] Rom. 1(, 17)], auß lauter gnaden, allein seligkeit von Gott geschenckt sey [Heb. 2[,] Rom. 1 (, 17)], auß lauter gnaden, allein
umb des verdienstes Christi willen [Ephes. 2(, 7-9) Rom. 3(, 24-25)]' (Heidelberger umb des verdienstes Christi
Katechismus 2009:180).

11.Frederick III concludes his preface with a call to all the readers, i.e. all the superintendents, ministers of the Word, preachers, those who serve in the churches and the schools of the Palatinate' ('allen und jeden Superintendenten, Pfarrherrn, Predigern, Kirchen[-] und Schuldienern'; Frederick III 2009:174):

'We do herewith affectionately admonish and enjoin upon every one of you, that you do, for the honour of God and our subjects, and also for the sake of your own soul's profit and welfare, thankfully accept this proffered Catechism or course of instruction, and that you do diligently and faithfully represent and explain the same according to its true import, to the youth in our schools and churches, and also from the pulpit to the common people, that you teach, and act, and live in accordance with it, in the assured hope, that if our youth in early life are earnestly instructed and educated in the Word of God, it will please Almighty God also to grant reformation of public and private morals, and temporal and eternal welfare.' (Frederick III ibid:175, translation by Van Vliet 2011:1)

12.The interesting fact is that the Confessio helvetica posterior was later presented to Frederick III himself, as he has requested confessional support from Bullinger on various occasions, but especially in 1565 .

13.'[...] weil wir in der lehr und instituierung der jugendt allerley unrichtigkeit und ungleichheyt befunden, darauß nit geringe mißverständ und unordnung erwecket und entstanden, das hiedurch solche mengel abgeschnitten und hinfürther ein gewisse und bestendige form und maß gehalten wurde' (Frederick III 1969:335). 
Word of God (Frederick III ibid:335). Frederick III underlines the trustworthy character of the 'lehr' [teaching] and 'instituierung' [instruction] of the youth. It is his contention that, through the teaching as well as the external ceremonies, the youth should be guided to the 'proper knowledge of the divine Word and will in a concerted and coherent way, based on Holy Scripture' (Frederick III ibid:335). ${ }^{14}$

It is consequently not too much of a stretch to conclude that when Frederick III says, concerning the Palatine Church Order, that its main purpose is the dissemination of the saving Word of God and the Christian edification of the subjects of the Palatinate, he is also referring to the HC (Frederick III 1969:335). ${ }^{15}$

\section{The Palatine Church Order of 1563 The status of the Church Order of the Palatinate}

Although the two prefaces of Frederick III and the Palatine Church Order were composed in 1563 - the year in which the $\mathrm{HC}$ and the Church Order were both authorised and published - there is one crucial difference between the prefaces on the one hand and the Church Order on the other. Unlike the two prefaces, the text of the Church Order was officially sanctioned and consequently has authoritative status (cf. Lurz 1998:74). ${ }^{16}$ Furthermore, because of the confessional features of a church order (according to the reformed view of the church; cf. Niesel 1938:v), the fact that the HC is included in the Church Order and the manner in which it is embedded in the document, point to the close relationship between the purpose of the Catechism and the concrete application of it. ${ }^{17}$ Hence, the Church Order's introduction to the HC and other related remarks are of particular importance concerning the teaching character of the Catechism.

\section{The Catechism - Embedded in the context of the proclamation of the Word}

In the Palatine Church Order of 1563, the introduction to the catechism - 'On the Catechism' ('Vom cathechismo'; Sehling 1969:341-342) - gives us an important insight into the place and function of the $\mathrm{HC}$ with regard to its origins as well as into the intention of its authors and the churches of the Palatinate. ${ }^{18}$ It is worth noting that this introductory section is situated relatively early in the Church Order,

14.'[...] zugleich in der lehr und auch in den eusserlichen ceremoniis zu rechter erkandnuß göttliches worts und willens durch einen einträchtigen und in der heiligen schrift gegründten weg gebracht und geführt möchten werden' (Frederick III 1969:335).

15.'[...] so seind wir der ungezweiften zuversicht, das werde zur außbreitung deß seligmachenden worts Gottes, auch christlicher auferbauung unserer underthonen gelangen' (Frederick III ibid:335).

16.'So haben wire in kurtze kirchenordnung, welcher gestalt sich der kirchendiener in verkündigung göttliches worts, administrierung der heiligen sacramenten und anderm in den kirchen unsers churfürstenthumbs durchauß einhelliglich verhalten sollen, oberzehlter ursachen halben durch unsere fürnemen theologen, verhalten sollen, oberzehlter ursachen halben durch unsere fürnemen theologen, superintendenten, kirchendiener und andere gottselige, gelehrte menner und räthe
begreifen, besichtigen und endtlich in truck ausgehen lassen' (Sehling 1969:335). begreifen, besichtigen und endtlich in truck ausgehen lassen' (Sehling 1969:335).
Also refer to Lurz (1998:74): 'Der Text der KO [Palatine Church Order] wird von der Pfälzischen Synode verabschiedet und am 15.11.1563 offiziell eingeführt'.

17.Niesel (1938:v): 'Nach reformierter Lehre trägt auch die Ordnung der Kirche bekenntnismäßigen Charakter. Wie eng Bekenntnis und Ordnung der Kirche zueinander gehören, kann jeder sehr schön an der kurpfälzischen Kirchenordnung erkennen, in der der Heidelberger Katechismus eingebettet ist. Die Kirche bezeugt mit ihrem Bekenntnis wie mit ihrer Ordnung, daß Jesus Christus ihr Herr ist'

18.Due to space constraints, the part of the Church Order dealing with teaching and preaching ('Von der lehr und predigt'; cf. Sehling 1969:336-337), by which the regular church service is meant, is not dealt with here. directly after the formulary for baptism, which is preceded by the two introductions to the first parts, that is (1) on prayer and (2) on teaching and preaching. ${ }^{19}$ The placement of the catechism and its introduction at the very beginning of the Church Order, within the immediate context of prayer, preaching and the two sacraments (the catechism is situated between the baptism and the Lord's Supper),$^{20}$ indicates not only an emphasis on the teaching of the catechism, but also highlights the fact that the $\mathrm{HC}$ and the teaching thereof is seen as essential to the whole question of the edification of the church and the Reformation per se. Of course, it also underscores the role of the catechism in guiding a church member from receiving the covenant sign of God's promises (baptism) to the point of embracing these promises in faith (Lord's Supper).

In this regard, the introduction to baptism as well as the accompanying baptism formulary (Sehling 1969:337-341), includes some important notes on the teaching of children. One example is found in the prayer of thanksgiving at the end of the formulary where the Christian education ('daß es christlich und gottselig auferzogen werde'; Sehling ibid:341) of the child is mentioned. The second example is in the words to the congregation at the end of the formulary, which address the friends and relatives, and especially the fathers and godfathers (i.e. parents and godparents). They (the parents and godparents) should spare no pains ('ihr solt [...] allen fleiß anwenden'; Sehling ibid):

... in educating the child [...] for the Lord Christ in the real knowledge and fear of God according to the articles of the Christian faith and the teaching, which has been revealed by God from heaven and is contained in the Old and New Testament ... (p. 341) $)^{21}$

It is within the context of this education that the catechism, which directly follows the formulary for baptism, should be applied.

\section{'On the Catechism'}

The introductory exposition on the topic of catechism in the Palatine Church Order starts with a definition of catechism and outlines the aim of catechism (Sehling 1969):

Catechism in our Christian religion means a short and simple oral account of the most significant parts of Christian teaching, concerning which the young and unlearned [einfeltigen $=$ simpleminded or unlearned] are questioned, which questions they must answer with what they have learned. (p. 341 $)^{22}$

19.The sequence of the contents of this first section of the Palatine Church Order is as follows:

- Eingang der predig und ermahung zum gebeth für die predig [An introduction to sermons and exhortation to prayer for the sermon]

- Von der lehr und predig [Concerning the teaching and the proclamation/sermon] - Vom h. [eiligen] tauf [Concerning the holy baptism]

- Form zu taufen[Formula for the baptism]

- Form zu taufen[Formula for the baptism]

- Vatechismus [Catechism, i.e. the Heidelberg Catechism]

20.This first section of the Church Order could be subtitled: 'The proclamation of the Word'.

21.Sehling (1969:341): 'das diß kind in rechter erkandtnuß und forcht Gottes laut der artickel des christlichen glaubens und der lehre, welche von Gott auß dem himel offenbaret und im alten und neuen testament begriffen ist, dem herrn Christo auferzogen werde'.

22.'Catechismus in unser christlichen religion heist ein kurtzer und einfeltiger, mündtlicher bericht von den fürnemsten stücken der christlichen lehr, darin von den jungen und einfeltigen widerumb gefordert und gehört wird, was sie gelernet den jungen und einfeltigen waben' (Sehling 1969:341).
haben 
In this context, einfeltigen indicates those who have a lack of knowledge of Scripture and faith, rather than those with cognitive disabilities. What is interesting, however, is that catechetical teaching is not aimed at the youth alone, but also at other members of the church who lack knowledge of Scripture. The holistic point of departure in teaching is explicitly mentioned again. Relating to the Early Church, the three classical spheres of religious teaching (home, school and church) are included (Sehling 1969):

For all pious people from the commencement of the Christian Church have been careful to instruct their children in the fear of the Lord at home as well as in schools and churches - and undoubtedly for the following reasons - which should also incite us thereto. (p. 341) ${ }^{23}$

Thereafter the introduction on the Catechism furnishes three main reasons for this instruction.

Firstly, as the natural depravity of the heart ('angeborne boßheyt') will prevail, leading to the dismantling of church and civil authorities, only sound teaching ('heilsamer lehr'; cf. Tt 2:1) can counter it. ${ }^{24}$

Secondly, the Church Order substantiates the use of the HC in the teaching of the children by referring to the explicit commandment (außtrucklich bevelch) of the Lord. Here, the Church Order (after mentioning Ex 12:26-27,25 13:8-9, 14; Dt 4:37-40; 6:1-9; ${ }^{28}$ 11:18-21) ${ }^{29}$ quotes Deuteronomy 6:6-7:

23.'Dann es haben alle gottseligen von anbegin der christlichen kirchen sich beflissen, ihre kinder daheim [at home], in schulen und kirchen in der forcht des herrn zu underweisen one zweifel auß nachfolgenden ursachen, welche uns auch billig dazu bewegen sollen' (Sehling 1969:341; see Huckaby 2009 for English translation).

24.'Dann erstlich haben sie wol bedacht, daß die angeborne boßheyt uberhand nemen würde und darnach kirchen und politische regiment verderben, wann man ihr nit beyzeiten mit heilsamer lehr begegnet' (Sehling 1969:341).

25.Exodus 12:26-27: ${ }^{26}$ And when your children ask you, "What does this ceremony mean to you?" ${ }^{27}$ then tell them, "It is the Passover sacrifice to the LORD, who passed over the houses of the Israelites in Egypt and spared our homes when he struck down the Egyptians."

26. Ex 13:8-9, 14: ${ }^{8}$ On that day tell your children, "I do this because of what the LORD did for me when I came out of Egypt." ${ }^{9}$ This observance will be for you like a sign did for me when lcame out of Egypt." This observance on your hand and a reminder on your forehead that this law of the LORD is to be on your lips. For the LonD brought you out "Egypt with his mighty hand. [...] ${ }^{14}$ In "With a mighty hand the LoRD brought us out of Egypt, out of the land of slavery."

27.Deuteronomy 4:37-40: ${ }^{37}$ Because he loved your ancestors and chose thei descendants after them, he brought you out of Egypt by his Presence and his great strength, ${ }^{38}$ to drive out before you nations greater and stronger than you and to bring you into their land to give it to you for your inheritance, as it is today. ${ }^{39}$ Acknowledge and take to heart this day that the LORD is God in heaven above and on the earth below. There is no other. ${ }^{40} \mathrm{Keep}$ his decrees and commands, which I am giving you today, so that it may go well with you and your children after you and that you may live long in the land the LORD your God gives you for all time.'

28.Deuteronomy 6:1-9: " 1 These are the commands, decrees and laws the LORD your God directed me to teach you to observe in the land that you are crossing the God directed Jordan to possess, 2 so the you, your children and their children after them may ear the LORD your God as long as you live by keeping all his decrees and commands that I give you, and so that you may enjoy long life. ${ }^{3} \mathrm{Hear}$, Israel, and be carefu to obey so that it may go well with you and that you may increase greatly in a land flowing with milk and honey, just as the LORD, the God of your ancestors, promised you. ${ }^{4}$ Hear, O Israel: The LORD our God, the LORD is one. ${ }^{5}$ Love the LORD your God with all your heart and with all your soul and with all your strength. ${ }^{6}$ These commandments that I give you today are to be on your hearts. ${ }^{7}$ Impress them on your children. Talk about them when you sit at home and when you walk along the road, when you lie down and when you get up. ${ }^{8}$ Tie them as symbols on your hands and bind them on your foreheads. ${ }^{9}$ Write them on the doorframes of your houses and on your gates.

29.Deuteronomy 11:18-21: "18 Fix these words of mine in your hearts and minds; tie them as symbols on your hands and bind them on your foreheads. ${ }^{19}$ Teach them to your children, talking about them when you sit at home ${ }^{20}$ Write the walk long the road, when you lie down and when you get up. 2 write them on the doorframes of your houses and on your gates, 2" so that your days and the days of your children may be many in the land the LORD swore to give your ancestors, as many as the days that the heavens are above the earth.'
${ }^{6}$ These commandments that I give you today are to be on your hearts. ${ }^{7}$ Impress them on your children. Talk about them when you sit at home and when you walk along the road, when you lie down and when you get up.

Thirdly, the necessity of teaching the children (and other unlearned) by means of a catechism is deduced from both the history of revelation in the Old Testament as well as from church history (Sehling 1969:341). This was the case 'till Satan, through the antichrist, the pope', demolished this practice of catechetical teaching by replacing it with the ' $[F]$ irmung' (i.e. the 'confirmation'; Sehling ibid:342). ${ }^{30}$ Here, the Reformation's intention with catechetical teaching generally, and in presenting the $\mathrm{HC}$ in particular, is quite clear: it is in direct opposition to the practice of the Roman sacrament of 'confirmation'. The sound teaching of the catechism is necessary as a corrective remedy.

\section{The way the catechism should be used ...}

\section{Reciting the catechism}

Under the subheading about the form in which the catechism teaching should be done ('Soll derhalben der catechismus auf nachfolgenden form gehalten werden'; Sehling 1969:342), the method of using the catechism in the churches (congregations) is discussed. The discussion outlines the necessity of the public and corporate reading of an excerpt from the catechism every Sunday and on religious holidays ${ }^{31}$ in all the villages, towns and cities. The excerpt should be read in a way that renders the catechism clear and understandable. Taking into account the fact that most adults in those days would have been illiterate, one can understand the impact of this requirement.

What is of interest, though, is that the Church Order not only determines that the catechism be read in these churches. It also prescribes down to the finest detail (the 'Lord's Day' or even the specific question) which sections of the catechism should be read in order to get through the whole catechism over the course of nine successive Sundays ('das er in neun Sontagen außgelesen werde'; Sehling 1969:342).

\section{Preaching the catechism}

Subsequent to the stipulation about reciting the whole catechism over the course of nine Sundays, the Church Order then gives the second requirement for using the catechism in the congregation, namely the preaching of it on Sunday afternoons at a time that suits the individual locations. ${ }^{32}$ Again, with regard to all the elements (hymn,

30. In this case, the translation of the concept [F]irmung with 'the true foundation on the Heidelberg Catechism Project website (cf. Huckaby 2009) is incorrect. The reason is that the term [F]irmung does not mean 'true foundation' in this context, but refers to the Roman Catholic practice or ceremony known as 'Confirmation', which has become a sacrament since medieval times. 'Firmung' is a German translation of the Latin (theological) concept of 'confirmation'. This practice is adopted in part in the Lutheran tradition, although without sacramental character, called 'Konfirmation' in modern German. For current Anglican views on 'confirmation', see Turrell (2006).

31.'[...] an allen Son- und feiertagen' (Sehling 1969:342). One should keep in mind that at that stage of history, all public holidays ('Feiertage') were religious - a fact that is confirmed by the etymology of the concept 'holiday' (= holy day).

32.'Ferner soll alle sontagnachmittag zu der stund, die einem jeden ort gelegen ist, catechismuspredigt also gehalten werdern.' (Sehling 1969:342) 
prayer, reading from Scripture and Decalogue), ${ }^{33}$ the Church Order prescribes the exact manner and order according to which this catechism service should be conducted. After this, the Church Order stipulates the way in which the minister should explain the catechism. He should focus first on the text and then on the various questions, taking into account those who cannot learn the questions that are expounded. ${ }^{34}$ Thereafter, the minister should let some of the young people recite specific questions in the catechism, namely those that were the subject of the sermon just prior to the teaching of the catechism and, more importantly, those that are going to be treated in the next sermon. These questions should have been learned and memorised beforehand, at school or at home. For this very reason, the catechism has been divided into Sunday sections (sections for the Lord's Day). ${ }^{35}$ Subsequently, after these questions have been recited by some in the presence of the congregation, the minister should give a brief and clear explanation of several of the next questions with the aim of preaching on the whole catechism at least once during the course of each year. ${ }^{36}$

\section{Conclusion}

As the ruler of the Palatinate, Frederick III's focus regarding the faith, education and the edification of his subjects, centred on the honour of God, on the one hand, and the church of the Lord Jesus Christ, ${ }^{37}$ particularly the youth, on the other. His concern that the youth of his principality would grow up with a lack of fear of God and a lack of knowledge of his Word weighed heavily on him. In his two prefaces, he therefore repeatedly stresses the urgent need for a solid biblical catechism. There is one solution to the ignorance of the youth and other people: comprehensive and thorough instruction. In this instruction, the correct use of the $\mathrm{HC}$ is crucial in producing sufficient knowledge of Scripture and a living faith in the Lord of Scripture amongst the youth as well as the rest of the subjects of his principality. In this regard, religious education is not only the responsibility of the church, but also that of the families and the schools, and teaching the Word of God is not only the task of the minister, but also that of the parents and the teachers. Frederick III, and the men responsible for such matters, opted for a holistic and comprehensive approach to teaching, since teaching the HC is, amongst other things, the obedient answer to the Lord's decree in Deuteronomy 6:6-7 to teach his Word diligently.

33.'[...] daß der kirchendiener furs erst nach dem gesang das vaterunser bete und Gott umb rechten verstand seins worts anrufe, darnach die zehen gebot verstendtlich dem volck fürlese' (Sehling 1969:342).

34.'Darauf soll er die angehenden, welche die fragen, so gepredigt werden, noch nit lernen können, verhören und ordenlich erstlich ein zeit lang auf die text, darnach auch allgemach auf die fragstück anleiten' (Sehling 1969:342).

35.'Nach diesem lasse er etliche under der jugend ein gewisse anzal fragen im catechismo (wie wir dann denselben umb sieser ursach willen in Sontage theilen haben lassen), so in vorgehenden und sonderlich in der nechsten predigt erkläret worden und sie zuvor in der schul oder daheim gelernet, aufsagen' (Sehling 1969:342)

36.'Und wann dise also in beysein der gemein von etlichen aufgesagt worden, soll der kirchendiener etliche folgende fragen einfeltig und kürtzlich erklären und außlegen, also das er den catechismum zum wenigsten einal alle jar außpredige' (Sehling 1969:342)

37.Cf. question 54 of the HC: 'What do you believe concerning 'the holy catholic church? I believe that the Son of God through his Spirit and Word, out of the entire human race, from the beginning of the world to its end, gathers, protects, and preserves for himself a community chosen for eternal life and united in true faith. And of this community I am and always will be a living member.'
The knowledge and fear of the Lord, which can only be achieved by proclaiming the Word of God, are considered central to the aim and purpose of teaching the HC. There is no contradiction between Scripture as the Word of God and the HC. Of course, this does not at all imply that the HC is considered equal to Scripture or that it has the same inherent authority as Scripture. Rather, it should be understood within the context of a key principle of the Reformation, namely that the preaching of the Word of God is the Word of God (praedicatio verbi Dei est verbum Dei). Even the setting of the HC early in the Palatine Church Order, between the sacraments of baptism and the Lord's Supper, accentuates this aspect.

The HC did not merely have theoretical purposes. Its character, contents and structure were carefully composed to briefly and simply teach the most significant parts of the Christian faith to the whole congregation, but particularly to the young and the uneducated. The teaching was meant to be regular and frequent, with much repetition. In this sense, teaching the $\mathrm{HC}$ as sound doctrine was also explicitly intended as a direct remedy for the Roman malpractice of 'confirmation'. The youth should be able to learn at home, in the schools and in the church, until they have advanced sufficiently in their knowledge of Scripture and faith and are able to comprehend the Gospel.

Therefore, teaching the $\mathrm{HC}$ does justice to the biblical command that the gospel should be proclaimed, should be preached, should be taught - and should be learned and understood. Hence, it is fair to say that the words of Deuteronomy 6 resonate in the background when the $\mathrm{HC}$ is being taught and learned: 'And thou shalt teach these words diligently ...'

\section{Acknowledgements Competing interests}

The author declares that he has no financial or personal relationship(s) that may have inappropriately influenced him in writing this article.

\section{References}

Faulenbach, H., 2002, 'Einleitung', in H. Faulenbach \& E. Busch (eds.), Reformierte Bekenntnisschriften, vol. 1/1, pp. 1-7, Neukirchener, Neukirchen.

Frederick III., [1563] 1969, ['Vorwort' am 19.11.1563], in E. Sehling (ed.), Die evangelischen Kirchenordnungen des XVI. Jahrhunderts (14. Band: Kurpfalz), pp. 333-335, J.C.B. Mohr (Paul Siebeck), Tübingen.

Frederick III, [1563] 2009, 'Vorwort zum Heidelberger Katechismus', in A. Mühling \& P. Opitz (eds.), Reformierte Bekenntnisschriften, vol. 2/2 1562-1569, pp. 174-175, Neukirchener.

Gunnoe, C.D. Jr., 2005, 'The reformation of the Palatinate and the origins of the Heidelberg Catechism, 1500-1562', in L.D. Bierma (ed.), An Introduction to the Heidelberg Catechism. Sources, history and theology, p. 15, Baker Academic, Grand Rapids.

Gruch, J., 1996, 'Deutschsprachige Drucke des Heidelberger Katechismus: 1563-1800', Beiträge zur Katechismusgeschichte vol. 1, ß-Verlag, Köln.

Heidelberger Katechismus, [1563] 2009, in A. Mühling \& P. Opitz (eds.), Reformierte Bekenntnisschriften, vol. 2/2 1562-1569, pp. 174-212, Neukirchener, Neukirchen.

Hollweg, W., 1968, Neue Untersuchungen zur Geschichte und Lehre des Heidelberger Katechismus, Zweite Folge, Neukirchener, Neukirchen. 
Huckaby, C., 2009, 'The Palatinate Church Order of 1563 - Why the Catechism', in Heidelberg Catechism Project, viewed 30 October 2012, from http://www.
heidelbergcatechismproject.com/palatinate-church-order-of-1563-why-thecatechism/

Langerak, N.J., 2010, 'Antithetical catechizing in the twenty-first century', Protestant Reformed Theological Journal 44(1), 27-60.

Lurz, F., 1998, Die Feier des Abendmahls nach der Kurpfälzischen Kirchenordnung von 1563. Ein Beitrag zu einer ökumenischen Liturgiewissenschaft, Kohlhammer, Stuttgart.

Neuser, W.H., 2009, 'Heidelberger Katechismus von 1563', in A. Mühling \& P. Opitz (eds.), Reformierte Bekenntnisschriften, vol. 2/2 1562-1569, pp. 167-173, Neukirchener, Neukirchen.
Niesel, W., 1938, Bekenntnisschriften und Kirchenordnungen der nach Gottes Wort reformierten Kirche, Evangelischer Verlag, Zürich.

Sehling, E., 1969, Die evangelischen Kirchenordnungen des XVI. Jahrhunderts, vol. 14 Kurpfalz, J.C.B. Mohr (Paul Siebeck), Tübingen.

Turrell, J.F., 2006, 'Muddying the waters of baptism: The Theology Committee's report on baptism, confirmation, and Christian formation', Anglican Theological Review 88(3), 341-359.

Van 't Spijker, W. (ed.), 2005, Het troostboek van de kerk. Over de Heidelbergse Catechismus, Den Hertog, Houten. PMid:15932137

Van Vliet, J., 2011, Discussion guide concerning the Heidelberg Catechism anticipating its 450th anniversary 1563-2013, viewed 31 October 2012, from http://www. canadianreformedseminary.ca/general/resources.html 